\title{
Characteristics of Lymphocytes Appearing in Persistent Lymphocytosis Induced Experimentally in Cattle by Bovine Leukemia Virus Infection
}

\author{
Yuji KONO, Shigeyoshi ITOHARA, Susumu MURAMATSU ${ }^{1)}$, Hiroshi SENTSUI, Seishi ISHINO, \\ and Kenji SEKIKAWA \\ National Institute of Animal Health, Tsukuba, Ibaraki 305, ') National Institute of Animal Industry, Tsukuba, Ibaraki \\ 305, Japan
}

(Received 15 June 1988/Accepted 10 September 1988)

ABSTRACT. Properties of peripheral blood lymphocytes (PBL) appearing during persistent lymphocytosis (PL) of cattle that was induced by inoculation of a large number of bovine leukemia virus (BLV)-infected lymphocytes were studied. The PBL possessed surface immunoglobulin at a high ratio and had high syncytium-forming activity. The PBL could not be distinguished from normal PBL cytogenetically. These PBL were shown to be polyclonal cells integrating BLV-proviral DNA randomly into their cellular DNA. These properties were similar to those of PBL appearing at the stage of PL of cattle naturally infected with BLV. The BLV-proviral DNA content of PBL and transcription of viral genes increased in parallel with development of PL and decreased along with a decline of PL indicating the possibility that gene expression and activation of BLV play an important role in induction and maintenance of PL. KEY WORDS: bovine leukemia virus, cytogenetics, molecular biology, persistent lymphocytosis, surface immunoglobulin.

Some cattle develop persistent lymphocytsis (PL) during the course of natural infection with bovine leukemia virus (BLV) [2, 4]. Major cell population of peripheral blood lymphocytes (PBL) at the time of PL (PLL) have characteristics of $B$ lymphocytes $[22,26,29,30]$, show cytogenetic properties indistinguishable from those of noninfected cattle [7], produce a large number of infective $\mathrm{BLV}[13,28,36]$ and consist of polyclonal cells integrating BLV proviral genome at random sites in their cellular DNA [19].

BLV genome encodes trans-activator genes, which are essential for the expression of viral genes [16], and activate the bacterial chloramphenicol acetyl transferase gene directed by BLV-long terminal repeat (LTR) [18], at the $\mathrm{XBL}$ region that is located between env gene and 3' LTR [31, $33,34]$. The product of corresponding (pX) genes of human $\mathrm{T}$ cell leukemia viruses (HTLVs) [12, 35] which have many similar- ities to XBL genome activate IL-2 receptor and IL-2 gene expression which may give rise to $\mathrm{T}$ lymphocyte proliferation $[6,27]$. Therefore, it can be postulated that expression of the XBL genes have a role in promoting the division of $\mathrm{B}$ lymphocytes and inducing PL.

Integration and expression of the BLV genome in PBL of cattle chronically infected with BLV and cattle affected with enzootic bovine leukosis (EBL) have been studied [19-21], but there is no report on the BLV genome and its expression during the course of development of PL.

We reported in a previous paper [23] that cattle showed an increase in number of PBL suddenly after a latent period following inoculation of a large number of PLL. In this paper, characteristics of the PLL and the relationship between the rise and fall of the degree of PL and those of the BLV genome and its expression in PLL are described. 
MATERIALS AND METHODS

Cattle: The animals used were one calf (B69) which developed PL after inoculation of $6.4 \times 10^{8}$ tumorous cells in the blood of a cow with EBL, 7 cattle (B5, 6, 7, 8, 9, 64, 67) which developed PL after being inoculated with $2.4-240 \times 10^{7}$ PLL, 1 calf (B71) which failed to develop PL after inoculation of $200 \mathrm{~m} l$ of culture fluid of fetal lamb kidney cells persistently infected with BLV (FLK-BLV) [39], and 5 cattle (B1, 2, 3, 4, 23) which did not develop PL after inoculation of cell-free BLV were used. Details of these cattle were given in a previous paper [23].

Detection of surface immunoglobulin (sIg)-positive cells: $\mathrm{PBL}$ collected by gradient centrifugation were stained with FITC-labelled anti-bovine $\operatorname{IgG}(\mathrm{H}+\mathrm{L})$ serum (Cappel Laboratories, U.S.A.) by a routine method. The ratio of sIg-positive cells was determined by alternate observations of the same field by a fluorescence system and a phase contrast system of a microscope.

Syncytium-induction assay: The assay was performed as described previously [24].

Karyotype analysis: Analysis of individual karyotypes and chromosomal abnormalities of peripheral blood lymphocytes were performed by routine methods [10]. Twenty well-spread metaphases from each animal were analyzed. Lymphocytes cultured for 48 hours in a conventional medium containing 5-bromo-2'-deoxyuridine $(10 \mu \mathrm{g} / \mathrm{m} l)$ were stained and then examined by the fluorescent plus Giemsa (FPG) method for sister chromatid exchange (SCE) [17]. Twenty cells on average (16-24 cells) were analyzed for each animal.

Radiolabelled viral probes: The following DNA fragments were prepared from a full-length proviral clone [14]; $1.05 \mathrm{~kb}$ fragment containing BLV 5' LTR and a part of the gag gene for a LTR-gag probe [16], 6.8 $\mathrm{kb}$ fragment containing the gag, pol, and env genes for a representative (Rep) probe and $0.72 \mathrm{~kb}$ fragment of the XBL region for an XBL probe $[14,15]$. These fragments were labelled $\left(1-2 \times 10^{8} \mathrm{cpm} / \mu \mathrm{m}\right)$ with ${ }^{32} \mathrm{P}$ dCTP (New England Nuclear, U.S.A.) by the nick translation procedure [32].

DNA isolation and Southern blot hybridization: Cellular DNA was prepared from PBL and tumor cells by sodium dodecyl sulfate (SDS)-proteinase $\mathrm{K}$ treatment and phenol extraction.

Cellular DNA $(5 \mu \mathrm{g})$ was digested with restriction endonuclease (EcoRI or $P v u \mathrm{II}$ ), electrophoresed in $0.8 \%$ agarose, and blotted onto a nitrocellulose filter (Schleicher \& Schuell, West Germany) according to the procedure described by Southern [36]. The filters blotted with $E c o$ RI and $P v u I I$ digests were hybridized with the LTR-gag and Rep probes, respectively, at $42^{\circ} \mathrm{C}$ in a solution containing $50 \%$ formamide, $5 \times \operatorname{SSC}(1 \times$ SSC: $0.15 \mathrm{M} \mathrm{NaCl}, 0.015 \mathrm{M}$ Na citrate), $0.5 \%$ SDS, $1 \times$ Denhardt's solution $(1 \times$ Denhardt's: $0.02 \%$ each of polyvynylpyrrolidone, bovine serum albumin and Ficol 400), $0.01 \mathrm{M}$ ethylenediaminetetraacetic acid and salmon sperm DNA (100 $\mu \mathrm{g}$ per $\mathrm{m} l$ ), and washed at $68^{\circ} \mathrm{C}$ in $0.2 \times \mathrm{SSC}-$ $0.1 \%$ SDS. The filters were exposed to Kodak XAR-5 films at $70^{\circ} \mathrm{C}$ in the presence of $\mathrm{Du}$ Pont intensifying screens.

RNA isolation and dot blot hybridization: Total RNA was prepared from PBL and FLK-BLV cells by guanidine thiocyanate/ cesium chloride centrifugation [5]. RNA dot blot hybridization was carried out according to the procedures described by Thomas [38]. In brief, total RNAs from PBL $(5 \mu \mathrm{g})$ and FLK-BLV $(0.008-5 \mu \mathrm{g})$ were spotted onto the nitrocellulose filter saturated with $20 \times$ $\mathrm{SSC}$. The filter was hybridized with the $\mathrm{XBL}$ probe at $42^{\circ} \mathrm{C}$ in a solution of $50 \%$ formamide, $5 \times \mathrm{SSC}-50 \mathrm{mM}$ sodium phosphate $(\mathrm{pH} 6.5), 1 \times$ Denhardt's solution and dena- 


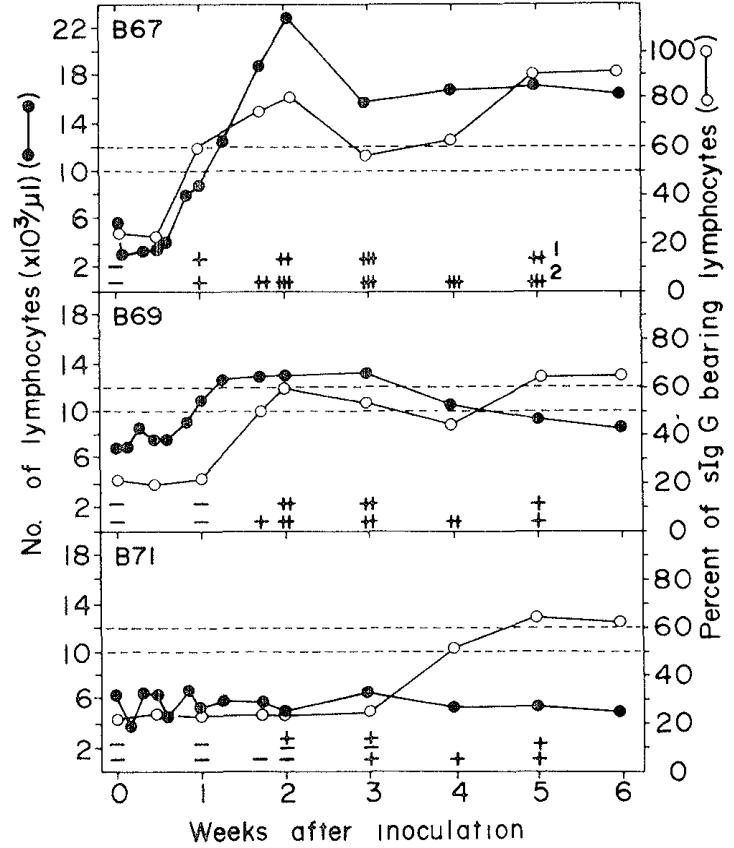

Fig. 1. Responses of calves after inoculation of various sources of BLV. B67, 69, and 71 were inoculated intravenously with $2 \times 10^{9} \mathrm{PLL}, 6.4 \times 10^{8}$ EBL cells and $200 \mathrm{~m} l$ of cell-free culture fluid obtained from FLK-BLV cells, respectively. The two dotted lines represent Bendixen's key [4] for determination of lymphocytosis. Values above the upper line, values between the two lines and values below the lower line indicate lymphocytosis, suspected lymphocytosis and normal, respectively. ${ }^{1}$ Detection of BLV genome in PBL. - \# : intensity of hybridized band shown in Fig. 3 was digitalized. ${ }^{2}$ Infectivity of PBL shown by the SIA. - H+: no syncytia, and 1-9, 10-50, 51-250 syncytia/ $1 \times 10^{5} \mathrm{PBL}$, respectively.

tured salmon sperm DNA $(250 \mu \mathrm{g} / \mathrm{m} l)$ and washed at $50^{\circ} \mathrm{C}$ in $0.1 \times \mathrm{SSC}-0.1 \% \mathrm{SDS}$.

\section{RESULTS}

Ratio of sIgG bearing cells: In 1 (B69) and 3 cattle (B40, 64, 67) which were inoculated with EBL cells and PLL, respectively, the ratio of sIg-bearing lymphocytes increased to 58 to $90 \%$ after development of PL from 18 to $40 \%$ before the inoculation. An increase in sIgG bearing cells was also observed in 3 cattle (B23, 68, 71) which failed to develop PL after inoculation of cell-free virus, but the ratio remained in a range of 45 to $65 \%$. Representative cases are shown in Fig. 1.

Syncytium-forming activity of $P B L$ : Seven cattle with or without PL were tested for the activity. It was higher in cattle with PL than in those without PL (Table 1). PBL of 2 cattle (B2 and 4) showed low syncytiumforming activity at the non-PL stage but the activity increased after development of PL which was induced by inoculation of a large number of PLL. In contrast, the activity was reduced when one animal (B22) recovered from PL.

Karyotype analysis: Chromosomal characteristics of 5 cattle were examined to disclose whether or not the lymphocytes propagated in recipient cattle originated in the donor lymphocytes. Karyotypes of a donor and 4 recipient were investigated when they developed marked PL. As shown in Table 2, PBL of the male donor had a characteristic karyotype of $59, \mathrm{XY} ; \mathrm{t}$ (Robertsonian translocation 1/29), while PBL of 2 male recipients showed no such translocation and those of 2 female recipients showed female karyotype, XX.

PBL obtained from 6 cattle with PL and 5 cattle without PL were investigated cytogenetically (Table 3). There was no difference in incidence of numerical and structural chromosomal abnormalities between the 2 groups. Structural chromosomal abnormalities consisted of chromatid gaps $(60.5 \%)$, chromatid breaks $(34.9 \%)$ and fragments $(4.7 \%)$. There was also no difference in frequency of SCE between the 2 groups. The rates of incidence of these chromosomal changes were in the normal range found in healthy cattle [10].

Analysis of viral genome in PBL: Donor and recipient $\mathrm{PBL}$ were examined for integration of $\mathrm{BLV}$ provirus to disclose the origin of the increased PBL in the recipient by Southern blotting analysis using the labelled LTR-gag probe. As shown in Fig. 2, PBL (circulating tumor cells) of a donor 
Table 1. Relationship between the number of PBL and their syncytium-forming activity

\begin{tabular}{ccccc}
\hline $\begin{array}{c}\text { Animal } \\
\text { No. }\end{array}$ & $\mathrm{dpi}^{\mathrm{a})}$ & $\mathrm{PL}$ & $\begin{array}{c}\text { Nos. of PBL } \\
\left(\times 10^{3} / \mu l\right)\end{array}$ & $\begin{array}{c}\text { Syncytium- } \\
\left.\text { forming activity }{ }^{\mathrm{b}}\right)\end{array}$ \\
\hline B1 & 412 & - & 6 & + \\
B3 & 412 & - & 6 & + \\
B5 & 402 & + & 19 & ++++ \\
B7 & 475 & + & 23 & ++++ \\
B2 & 412 & - & 7 & + \\
& 479 & + & 16 & ++++ \\
B4 & 412 & - & 7 & + \\
& 732 & + & 15 & ++++ \\
B22 & 99 & + & 16 & ++++ \\
& 402 & - & 6 & + \\
\hline
\end{tabular}

a) Days post inoculation with $\mathrm{BLV}$

b) + and ++++ : 1-9 and 51-250 syncytia per $1 \times 10^{5}$ lymphocytes

Table 2. Karyotype analysis of inoculated (donor) lymphocytes and increased (recipient) lymphocytes

\begin{tabular}{ccccc}
\hline \multicolumn{2}{c}{ Donor } & & \multicolumn{2}{c}{ Recipient } \\
\cline { 1 - 2 } Animal No. (Sex) & \multirow{2}{*}{ Karyotype } & & Animal No. (Sex) & Karyotype \\
\hline \multirow{2}{*}{ B9 (male) } & $\left.59, \mathrm{XY} ; \mathrm{t}^{\mathrm{a}}\right)$ & B5 $($ male) & $60, \mathrm{XY}$ \\
& & & B6 (male) & $60, \mathrm{XY}$ \\
& & & B21 (female) & $60, \mathrm{XX}$ \\
& & & B22 (female) & $59, \mathrm{XX} ; \mathrm{t}$ \\
\hline
\end{tabular}

a) Heterozygous Robertsonian 1/29 translocation

Table 3. Frequency of lymphocytes with cytogenetic abnormalities in cattle with or without persistent lymphocytosis after infection with BLV

\begin{tabular}{|c|c|c|c|c|c|c|c|}
\hline \multirow[b]{2}{*}{$\begin{array}{l}\text { No. of } \\
\text { cattle }\end{array}$} & \multirow[b]{2}{*}{$\mathrm{PL}$} & \multicolumn{3}{|c|}{ Chromosomal abnormalities } & \multicolumn{3}{|c|}{ Sister chromatid exchange (SCE) } \\
\hline & & $\begin{array}{l}\text { No. of cells } \\
\text { analyzed }\end{array}$ & $\begin{array}{c}\text { Numerical } \\
\text { abnormalities }\end{array}$ & $\begin{array}{c}\text { Structural } \\
\text { abnormalities }\end{array}$ & $\begin{array}{c}\text { No. of cells } \\
\text { analyzed }\end{array}$ & $\begin{array}{l}\text { No. of } \\
\text { SCE }\end{array}$ & $\begin{array}{c}\text { No. of SCE } \\
\text { per cell }\end{array}$ \\
\hline 6 & + & 120 & $2(1.7)^{a)}$ & $19(15.8)$ & 117 & 802 & 6.85 \\
\hline 5 & - & 100 & $4(4.0)$ & $18(18.0)$ & 100 & 743 & 7.4 \\
\hline \multicolumn{3}{|c|}{$\begin{array}{l}\text { Spontaneous } \\
\text { incidence in } \\
\text { normal cattle }^{\text {b) }}\end{array}$} & $\begin{array}{c}(2.4-4.9) \\
(3.5)^{\mathrm{c})}\end{array}$ & $\begin{array}{l}(8.0-20.0) \\
(16.6)\end{array}$ & & & $\begin{array}{c}5.9-8.8 \\
(7.1)\end{array}$ \\
\hline
\end{tabular}

a) Numbers in parentheses are the percent positive

b) Data investigated by Hanada and Muramatsu [10]

c) Average 


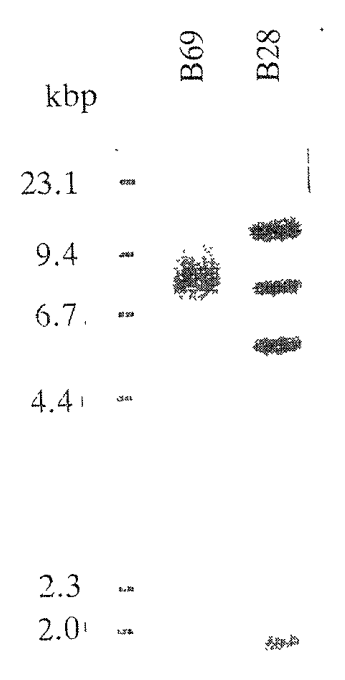

Fig. 2. Sites of integration of BLV proviruses in the genomes of PBL of a donor (B28: a cow affected with EBL) and a recipient (B69). Details of the recipient are shown in Fig. 1. Cellular DNA samples $(5 \mu \mathrm{g})$ were digested with EcoRI and examined with a labelled LTR-gag probe.

cow (B28) with EBL contained 2 copies of the $\mathrm{BLV}$ genome corresponding to four band, but randomly integrated BLV genome was found in PBL of a recipient (B69) by mean of smear band. These results indicate that $\mathrm{PBL}$ of recipient consist of newly infected polyclonal cells.

DNAs from PBL collected sequentially after inoculation from 3 calves were digested with restriction endonucleases and subjected to Southern blotting analysis. DNA samples digested with EcoRI were examined with the labelled BLV LTR-gag probe to detect the sites of integration of BLV provirus in the genomes of PBL. Those digested with $P v u I I$ were examined with the labelled Rep BLV probe to estimate the number of integrated viral copies in the cells.

As shown in Fig. 3-A, viral DNAs were detected by the LTR-gag probe from 1 and 2 weeks post inoculation (wpi) to 5 wpi in 2 calves (B67 and 69) in accordance with development of PL. The number of viral copies was reduced 5 wpi in $\mathrm{B} 69$ when the number of PBL recovered to nearly the normal range (Fig. 1). The viral genomes were found as smear during all stages of infection. In a calf, B71, that failed to develop PL the BLV genome could not be detected by the LTR-gag probe but was detected faintly 3 and 5 wpi by the Rep BLV probe.

Viral DNAs were also detected by the Rep BLV probe in parallel with the detection by the LTR-gag probe in PBL of the 2 calves (Fig. 3-B). The PBL were estimated to contain $1 / 3-1 / 2$ a copy of the BLV genome, which may be complete, per diploid cell, when compared with the intensity of hybridization with BLV genomes which were obtained from an EBL cell line containing $1 \mathrm{BLV}$ genome per diploid cell [15].

Transcription of the XBL region in PBL was investigated by RNA dot blot analysis. As shown in Fig. 4, the specific RNA derived from the XBL region was detected from 1 and 2 wpi in the 2 calves. The quantity of the RNA increased and decreased in parallel with the number of PBL. Also, sequential changes in the quantity coincided with those of proviral DNA in PBL. The quantity of the RNA was from $1 / 125$ to $1 / 25$ of that in FLK-BLV cells. The RNA was not detected in a calf (B71) which failed to develop PL.

\section{DISCUSSION}

A rapid increase in PBL was observed after a latent period following inoculation of cattle with a large number of PLL [23]. Karyotype analysis and molecular biological analysis of donor and recipient PBL showed that the increased PBL were derived from the recipient, not from the donor.

The majority of the PBL bore sIg. These PBL produced a large number of infective BLV. The PBL did not show the anomalous karyotype changes that are observed in 


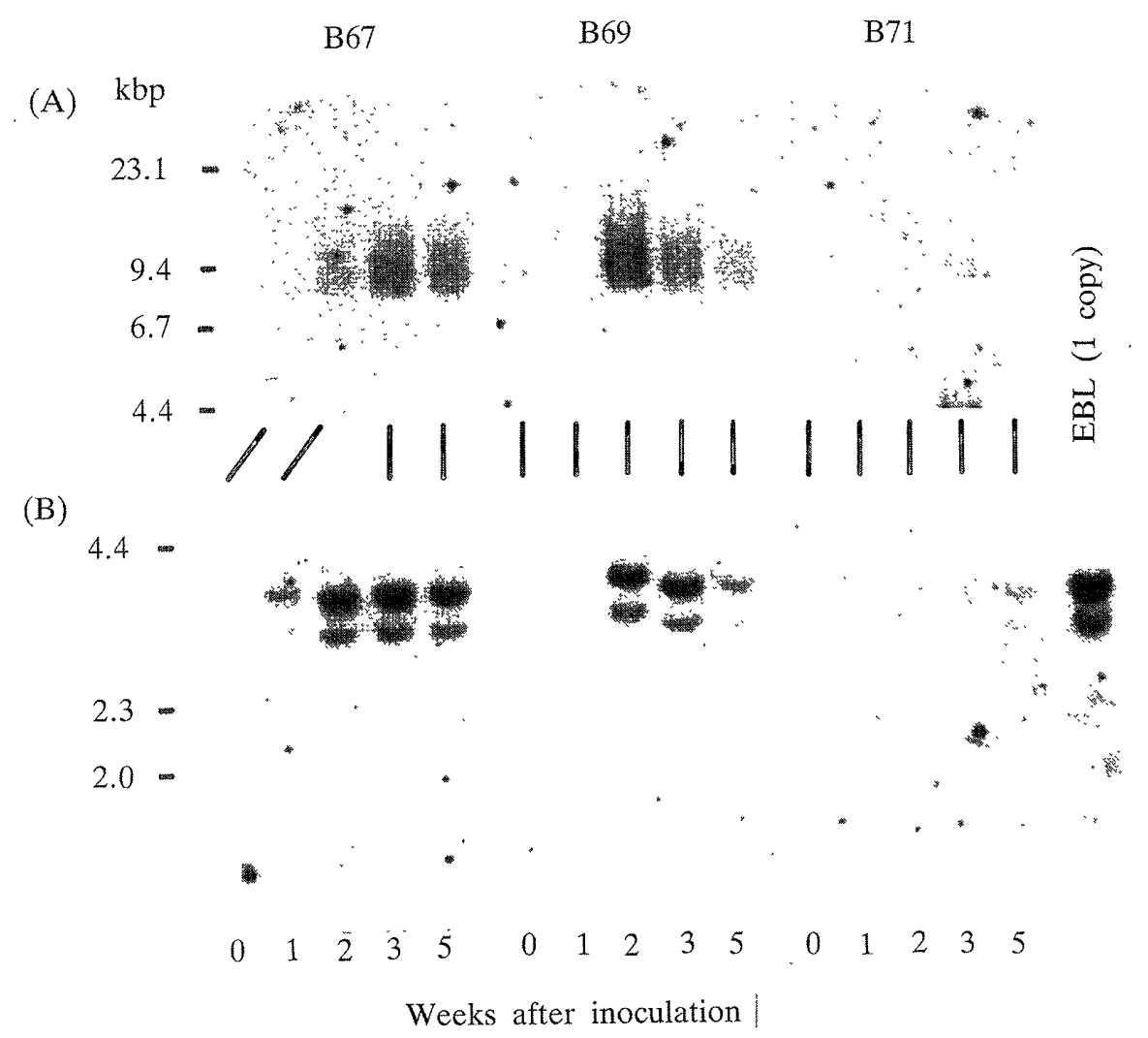

Fig. 3. Appearances of BLV proviruses in PBL after inoculation of BLV. (A): Cellular DNA samples $(5 \mu \mathrm{g})$ were digested with EcoRI and examined with a labelled LTR-gag probe. (B): The samples were digested with PuvII and examined with a labelled Rep BLV probe. The sample in the farthest right lane is a control containing $1 \mathrm{BLV}$ copy per diploid cell [15]. Details of the cattle are shown in Fig. 1.

cattle affected with EBL [7, 11], and their karyotypes were indistinguishable from the normal chromosomal pattern [10]. Furthermore, the increased PBL were shown to be polyclonal cells integrating BLV proviral genome at random sites. These characteristics of PLL were identical with those observed in PLL of cattle naturally infected with BLV [7, 13, 19, 22, 26, 28-30, 37].

A larger amount of BLV genome and higher infectivity were detected in PBL of cattle with PL than in those from cattle without PL. Also, the rise and fall in the number of PBL coincided with increase and decreases in the BLV genome in the PBL and infectivity of the cells. On the assumption that a diploid cell contains one proviral genome, it was estimated that aobut 30 to
$50 \%$ of the PBL in PL cattle contained the BLV genome. In contrast, only a small percentage of the PBL of non-PL cattle contained the BLV genome. Furthermore, although transcription of the BLV genome was detected in accordance with the increase in the BLV genome in PBL of PL cattle. These findings indicate the possibility that genome expression and replication of BLV play an important role in induction and maintenance of PL.

In this study, transcription of XBL genes, which are essential for the expression of viral genes directed by BLV-LTR $[16,18]$ and suspected of enhancing the growth of lymphocytes as shown in the case of HTLVs $[6,27]$, was found in accordance with the rise and fall in the number of PBL and in 
(A)

Weeks after Inoculationc

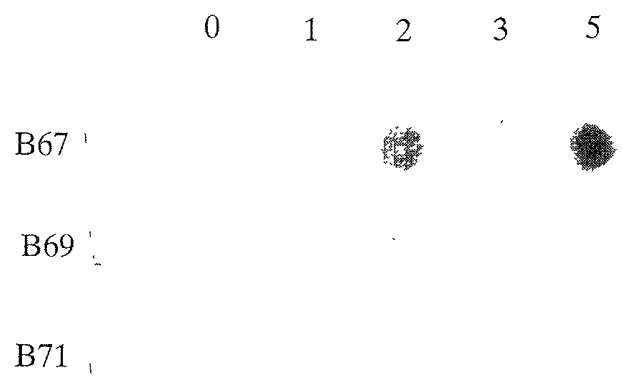

(B)

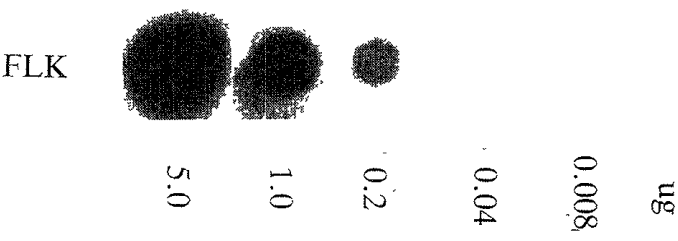

Fig. 4. (A): Appearance of XBL-region specific RNA in PBL of cattle infected with BLV. The RNA was detected by RNA ( $5 \mu \mathrm{g} /$ dot $)$ dot blot hybridization using a labelled BLV-specific DNA probe. Details of the cattle are shown in Fig. 1. (B): Positive control for the specific RNA. Cellular RNA extracted from FLK-BLV was diluted serially and tested.

parallel with the increase and decrease in BLV provirus in the PBL. Therefore, the expression of XBL genes may have a close relationship with development of PL, although it is not clear that the XBL gene function directly activate the BLV infected B lymphocytes. Studies of the relationship between the rise and fall of PL and appearance of a plasma factor which inhibits transcription of the BLV genome [8,9] may disclose the significance of the transcription of the XBL genes for the development of PL.

It has been shown that transcription of the BLV genome is not detected in cattle naturally infected with the virus [20], although some expression of the genome was suggested by an increase in specific antibodies during the course of development of lymphosarcoma [25]. However, we found the transcription of XBL region of bovine leukemia provirus in cattle at an early stage of infection in this study and also revealed expression of the provirus in the early stage as a transient viremia in a previous study [24]. Although the difference in results obtained in these studies seems to be derived from the difference in the stage of infection, a longer sequential investigation of cattle with PL will be useful to elucidate a state of BLV-genome expression during a stage of chronic infection.

Development of anti-BLV antibody which inhibits the maturation of BLV in vivo and in vitro $[1,3]$ did not suppress the transcription of $\mathrm{XBL}$ genes. This finding suggests the continuous expression of the genes during the stage of PL until development of the plasma factor $[8,9]$.

\section{REFERENCES}

1. Baliga, V., and Ferrer, J. F. 1977. Expression of the bovine leukemia virus and its internal antigen in blood lymphocytes: Proc. Soc. Exp. Biol. Med. 156: $388-391$.

2. Burny, A., Bex, F., Chantrenne, H., Cleuter, Y., Dekegel, D., Ghysdael, J., Kettmann, R., Leclerq, M., Leunen, J., Mammerickx, M., and Portetelle, D. 1978. Bovine leukemia virus involvement in enzootic bovine leukosis. pp. 251-311. In: Adv. Cancer Res. Vol. 28 (Klein G., and Weinhouse S. eds), Academic Press, New York.

3. Driscoll, D. M., Onuma, M., and Olson, C. 1977. Inhibition of bovine leukemia virus release by antiviral antibodies. Arch. Virol. 55: 139-144.

4. Ferrer, J. F. 1980. Lymphosarcoma. pp. 1-68. In: Adv. Vet. Sci. Comp. Med. Vol. 24 (Brandly C. A., and Cornelius C. eds.), Academic Press, New York.

5. Freeman, G. J., Cleyberger, C., DeKruyff, R. R., Rosenblum, D. S., and Cantor, H. 1983. Sequential expression of new gene programs in inducer T-cell clones. Proc. Natl. Acad. Sci. USA 80: 4094-4098.

6. Green, W. C., Leonard, W. J., Wano, Y., Svetlik, P. B., Peffer, N. J., Sodroski, J. G., Rosen, C. A., Goh, W. C., and Haseltine, W. A. 1986. Transactivator gene of HTLV-II induces IL-2 receptor and IL-2 cellular gene expression. 
Science 232: 877-880.

7. Grimoldi, M. G., Poli, G., Sartorelli, P., Cardora, C., Oldani, L., and Locatelli, A. 1983. Karyotype analysis of lymphocytes from cattle at different stages of bovine leukemia virus infection. Br. Vet. J. 139: 240-246.

8. Gupta, P., and Ferrer, J. F. 1982. Expression of bovine leukemia virus genome is blocked by a nonimmunoglobulin protein in plasma from infected cattle. Science 215: 405-407.

9. Gupta, P., Kashmiri, S. V. S., and Ferrer, J. F. 1984. Transcriptional control of the bovine leukemia virus genome: Role and characterization of a non-immunoglobulin plasma protein from bovine leukemia virus infected cattle. J. Virol. 50: 267-270.

10. Hanada, H., and Muramatsu, S. 1980. Spontaneous chromosome aberration rate in the peripheral lymphocytes of the Japanese Black cattle. Jpn. J. Zootech. Sci. 51: 803--805.

11. Hare, W. C. D., Yang, T. J., and McFeely, R. A. 1967. A survey of chromosome findings in 47 cases of bovine lymphosarcoma (leukemia). $J$. Natl. Cancer Inst. 38: 383-392.

12. Haseltine, W. A., Sodroski, J., Patarca, R., Briggs, D., Perkins, D., and Wong-Staal, F. 1984. Structure of 3' terminal region of type II human T lymphotropic virus: Evidence for new coding region. Science 225: 419-421.

13. Itohara, S., Oikawa, I., Terui, S., and Mizuno, Y. 1985. Infectivities of bovine leukemia virus in peripheral blood lymphocytes from naturally infected cattle and their relation to persistent lymphocytosis and antibody titers. Jpn. J. Vet. Sci.: 47: 807-810.

14. Itohara, S., and Sekikawa, K. 1987. Molecular cloning of infectious proviral genomes of bovine leukemia virus. Virology 159: 158-160.

15. Itohara, S., Sekikawa, K., Mizuno, Y., Kono, Y., and Nakajima, H. 1987. Establishment of bovine leukemia virusproducing and -nonrpoducing Blymphoid cell lines and their proviral genomes. Leukemia Res. 11: 407-414.

16. Itohara, S., Tomiyama, T., Ushimi, C., and Sekikawa, K. 1988. Cooperative regulation of bovine leukemia virus gene expression by two overlapping open reading frames in the XBL region. J. Gen. Virol. 69: 797-804.

17. Kato, H., and Sandberg, H. 1977. Effects of herpes simplex virus on sister chromatid exchange and chromosome abnormalities in human diploid fibroblasts. Exp. Cell Res. 109: 423-427.

18. Katoh, I., Yoshinaka, Y., Sagata, N., and Ikawa, Y. 1987. The bovine leukemia virus $\mathrm{X}$ region encodes a trans-activator of its long terminal repeat. Jpn. J. Cancer Res. (Gann) 78: 93-98.

19. Kettmann, R., Cleuter, Y., Mammerickx, M.,
Meunier-Rotival, M., Bernardi, G., Burny, A., and Chantrenne, H. 1980. Genomic integration of bovine leukemia provirus: Comparison of persistent lymphocytosis with lymph node tumor form of enzootic bovine leukosis. Proc. Natl. Acad. Sci. U.S.A. 77: 2577-2581.

20. Kettmann, R., Deschamps, J., Cleuter, Y., Couez, D., Burny, A. and Marbaix, G. 1982. Leukemogenesis by bovine leukemia virus: Proviral DNA integration and lack of RNA expression of viral long terminal repeat and 3' proximate cellular sequences. Proc. Natl. Acad. Sci. U.S.A. 79: 2465-2469.

21. Kettmann, R., Mammerickx, M., Portetelle, D., Gregoire, D., and Burny, A. 1984. Experimental infection of sheep and goat with bovine leukemia virus: Localization of proviral information in the target cells. Leukemia Res. 8: 937-944.

22. Koyama, H., Nagashima, H., Kajikawa, O., Yoshikawa, H., Tsubaki, S., Yoshikawa, T., and Saito, H. 1983. T and B lymphocytes in persistent lymphocytotic and leukemic cattle. Jpn. J. Vet. Sci. 45: 471-475.

23. Kono, Y., Sentsui, H., Arai, K., Matsuda, I., Ishino, S. 1989. Development and serial passage of persistent lymphocytosis associated with bovine leukemia virus infection in cattle. Jpn. J. Vet. Sci. 51: 60-69.

24. Kono, Y., Sentsui, H., Arai, K., Ishida, H., and Irishio, W. 1983. Contact transmission of bovine leukemia virus under insect-free conditions. Jpn. J. Vet. Sci. 45: 799-802.

25. Kono, Y., Sentsui, H., Miyamoto, T., Morozumi, K., and Sakamoto, Y. 1982. Changes in antibody titers in cattle infected clinically and subclinically with bovine leukemia virus. Int. J. Cancer 30: 655-657.

26. Kumar, S. P., Paul, P. S., Pomeroy, K. A., Johnson, D. W., Muscoplat, C. C., Van Der Maaten, M. J., Miller, J. M., and Sorenson, D. K. 1978. Frequency of lymphocytes bearing $\mathrm{Fc}$ receptors and surface membrane immunoglobulins in normal, persistent lymphocytotic and leukemic cows. Am. J. Vet. Res. 39: 45-49.

27. Maruyama, M., Shibuya, H., Harada, H., Hatakeyama, M., Seiki, M., Fujita, T., Inoue, J., Yoshida, M., and Taniguchi, T. 1987. Evidence for aberrant activation of the interleukin-2 autocrine loop by HTLV-1-encoded $\mathrm{P} 40^{\mathrm{x}}$ and $\mathrm{T} 3 / \mathrm{Ti}$ complex triggering. Cell 48: 1297-1305.

28. Miller, J. M., Miller, M. D., Olson, C., and Gillette, K. G. 1969: Virus-like particles in phytohemagglutinin-stimulated lymphocyte cultures with reference to bovine sarcoma. J. Natl. Cancer Inst. 43: 1297-1305.

29. Muscoplat, C. C., Johnson, D. W., Pomeroy, K. A., Olson, J. M., Larson, V. L., Stevens, J. B., 
and Sorensen, D. K. 1974. Lymphocyte surface immunoglobulin: Frequency in normal and lymphocytotic cattle. Am. J. Vet. Res. 35: 593-595.

30. Paul, P. S., Senogles, D. R., Muscoplat, C. C., and Johnson, D. W. 1979. Enumeration of T calls, B cells and monocytes in the peripheral blood of normal and lymphocytotic cattle. Clin. Exp. Immunol. 35: 306-316.

31. Rice, N. R., Stephens, R. M., Couez, D., Deschamps, J., Kettmann, R., Burny, A., and Gilden, R. V. 1984. The nucleotide sequence of the env gene and post-env region of bovine leukemia virus. Virology 138: 82-93.

32. Rigby, P. W. J., Dieckmann, M., Rhodes, C., and Berg, P. 1977. Labelling deoxyribonucleic acid to high specific activity in vitro by nick translation with DNA polymerase I. J. Mol. Biol. 113: 237-251.

33. Sagata, N., Yasunaga, T., Ohishi, K., TsuzukuKawamura, J., Onuma, M., and Ikawa, Y. 1984. Comparison of the entire genomes of bovine leukemia virus and human T-cell leukemia virus and characterization of their undefined open reading frames. EMBO J., 3: 3231-3237.

34. Sagata, N., Yasunaga, T., Tsuzuku-Kawamura,
J., Ohishi, K., Ogawa, Y., and Ikawa, Y. 1985. Complete nucleotide sequence of the genome of bovine leukemia virus: its evolutionary relationship to other retroviruses. Proc. Natl. Acad. Sci. U.S.A. 82: 677-681.

35. Seiki, M., Hattori, S., Hirayama, Y., and Yoshida, M. 1983. Complete nucleotide sequence of the provirus genome integrated in leukemia cell DNA. Proc. Natl. Acad. Sci. U.S.A. 80: 3618-3622.

36. Southern, E. M. 1975. Detection of specific sequences among DNA fragments separated by gel electrophoresis. J. Mol. Biol. 98: 503-517.

37. Stock, N. D., and Ferrer, J. F. 1972. Replicating $\mathrm{C}$-type virus in phytohemagglutinin-treated buffycoat cultures of bovine origin. J. Natl. Cancer Inst. 48: 985-996.

38. Thomas, P. S. 1979. Hybridization of denatured RNA and small DNA fragments transferred to nitrocellulose. Proc. Natl. Acad. Sci. U.S.A. 77: 5201-5205.

39. Van Der Maaten, M. J., and Miller, J. M. 1976. Replication of bovine leukemia virus in monolayer cell cultures. Comp. Leuk. Res., Bibl. Haematol. 43: 360-362.

\section{装約}

牛白血病ウイルス接種により実験的に牛に誘起された持続性リンパ球症時のリンパ球の症状：甲野雄次・糸原

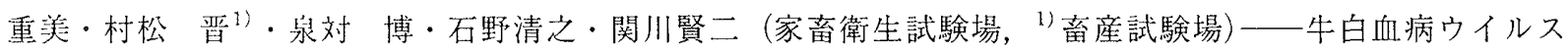
(BLV) 感染リンパ球の大量接種により発生した持続性リンパ球症（PL）時の末梢血リンパ球（PBL）の性状を 明らかにしたＰPLは表面免疫グロブリンを持ち，高いシンチウム形成能を示し，細胞遺伝学的には正常リン パ球と区別できなかった。また細胞 DNA 中にBLVプロウイルスDNA ランダムに取込んだポリクローナル な細胞群であった。これらの性状は BLVに自然感染したPL牛のPBLの性状と同一であった. PBLの BLVプ ロウイルス含有量とウイルス遺伝子の転写はPLの発現とともに増加し，その減衰とともに減少し，BLV遺伝 子の発現とウイルスの増殖が PLの成立と密接な関係を持つことを示唆した。 